\title{
UNIVERSITY OF CALIFORNIA, LOS ANGELES SCHOOL OF MEDICINE
}

\author{
DEPARTMENT OF BIOPHYSICS AND NUCLEAR MEDICINE \\ LABORATORY OF NUCLEAR MEDICINE AND RADIATION BIOLOGY \\ CONTRACT NO. AT (04-1) GEN-12
}




\section{DISCLAIMER}

This report was prepared as an account of work sponsored by an agency of the United States Government. Neither the United States Government nor any agency Thereof, nor any of their employees, makes any warranty, express or implied, or assumes any legal liability or responsibility for the accuracy, completeness, or usefulness of any information, apparatus, product, or process disclosed, or represents that its use would not infringe privately owned rights. Reference herein to any specific commercial product, process, or service by trade name, trademark, manufacturer, or otherwise does not necessarily constitute or imply its endorsement, recommendation, or favoring by the United States Government or any agency thereof. The views and opinions of authors expressed herein do not necessarily state or reflect those of the United States Government or any agency thereof. 


\section{DISCLAIMER}

Portions of this document may be illegible in electronic image products. Images are produced from the best available original document. 
UCLA 438

Biology and Medicine

UNIVERSITY OF CALIFORNIA, LOS ANGELES

SCHOOL OF MEDICINE

DEPARTMENT OF BIOPHYSICS AND NUCLLAR MEDICINE

IABORATORY OF NUCLEAR MEDICINE AND RADIATION BIOLOGY

ATOMIC ENERGY COMMISSION CONTRACT AT-(04-1)GEN-12

10875 LeConte Avenue

Ios Angeles 24, California

SUMMARY STATEMENT OF FINDINGS RELATED TO THE DISTRIBUTION, CHARACTERISTICS, AND BIOLOGICAL AVAILABILITY OF FALLOUP DEBRIS ORIGINATING

FROM TESTING PROGRAMS AT THE INEVADA TEST SITE

by

Kermit H. Larson, James W. Neel, and Associates

September 14,1960 
This report was prepared as an account of Government sponsored work. Neither the United States, nor the Commission, nor any person acting on behalf of the Commission:

A. Makes any warranty or representation, express or implied, with respect to the accuracy, completeness or usefulness of the information contalned in this report, or that the use of any information, apparatus, method, or process disclosed in this report may not infringe privately owned rights; or

B. Assumes any liabilities with respect to the use of, or for damages resulting from the use of any information, apparatus, method, or process disclosed in this report.

As used in the above, "person acting on behalf of the Commission" includes any employee or contractor of the Commission to the extent that such employee or contractor prepares, handles or distributes, or provides access to, any information pursuant to his employment or contract with the Comission. 
TABIE OF CONTENTS

Page No.

$\begin{array}{ll}\text { ABSTRACT } & 4\end{array}$

INTRODUCTION

FAILOUT PHENOMENOLOGY AND ITS CHARACTERISTICS

Characteristics of Fallout Patterns 9

'Local' Fallout Rainout Intensity Levels 10

Particle Size Distribution in Fallout Patterns 10

Radiochemical Properties of Fallout Debris 13

Solubility of Fallout Debris 14

Comparison of Properties of Fallout Debris from Balloon and

Tower-Supported Detonations 16

Radioactive Decay of Fallout Debris 17

Deposition of Radiostrontium in Areas Adjacent to Nevada

Test Site

22

BIOLOGICAL AVAILABILITY AS RELATED TO THE FATE AND PERSISTENCE

OF FALLOUT DEBRIS IN FALLOUT PATTERNS OUT TO 400 MILES FROM NEVADA TEST SITE

Distribution and Redistribution of Fallout Debris in Soils 24 Sr90 Contamination Levels in Nevada and Utah Soils 25

Fallout Debris Contamination of Forage Plants 28

Fission Product Accumulation by Native Animals 28

Strontium90 Contamination in Milk Produced in Nevada and

Utah

Experimentally-Determined Soil-Plant Factors which Affect

Sr90 and Cs137 Accumulation in Crops

SUMMARY AND CONCLUSION

ACKNOWLEDGMENTS

REFERENCES 
Page 4

\section{ABSTRACT}

Included in this report are summary statements of significant findings related to the distribution, characteristics, and biological availability of fallout debris originating from testing programs at the Nevada Test site during the past decade.

The delineation of fallout patterns has been accomplished by the use of aerial and ground monitoring surveys. Only about 25 per cent of the total amount of fission products produced by tower supported detonations was deposited within distances corresponding to fallout time of $\mathrm{H}+12 \mathrm{hrs}$; very much less was deposited by balloon-supported detonations. Fallout particles less than 44 microns in diameter are presumed to be of greatest biological significance. About 30 per cent of the fallout radioactivity from tower-supported detonations was contained in the 0 to 44 micron particles as compared to almost 70 per cent for balloon-supported detonations. Fallout debrls from balloon-supported detonations was also much more water and acid soluble than was the debris from tower-supported detonations. The < 44 micron fallout particles contalned a higher percentage of $\mathrm{Sr} 89,90$ and Rul03, 106 than did larger sized particles, and there was a higher percentage of these radioelements in the particles from balloon-supported detonations. Within distances corresponding to $\mathrm{H}+12$ hours fallout time, balloon-supported detonations deposited a maximum of 0.13 per cent of the theoretical total Sr89 produced; towersupported detonations deposited a maximum of 2 per cent. Tower-supported detonations also deposited a maximum of 7.2 per cent of the theoretical. total amount of Sr90 produced. Beta decay curves approximated the $\mathrm{T}^{-1.2}$ decay expression from $\mathrm{H}+12$ to $\mathrm{H}+6000$ hours; gamma decay curves deviated to the extent that irradiation doses calculated by the observed decay values were 1.5 to 2 times greater than those calculated by the $\mathrm{T}^{-1.2}$ relationship.

Fallout radioactivity is apparently confined to the first 2 inches of the soil surface unless the surface had been mechanically disturbed. Most of the fallout debris that was redistributed by various environmental factors after orlginal deposition consisted of particles less than 44 microns in diameter; the particles in this size range also represented the predominant contamination on plant follage. Sr90 levels in surface soil ranged from 31.9 to $142 \mathrm{mc} / \mathrm{sq}$. mile in virgin areas near known fallout pattern midlines and from 7.5 to $22.7 \mathrm{mc} / \mathrm{sq}$. mile in agricultural areas which did not necessarily coincide with fallout pattern midlines. The accumulation of radioiodine by native animals was observed to be a function of distance from Ground Zero. Radiobarium-140, Y-91, Sr89 and Sr90 were major bone contaminants. Post-series sampling of native animals indicated that the accumulation of $5 r 89$ was also a function of distance from the point of detonation; however, the Sr90 accumulation by animals correlated poorly with the strontium unit levels in soils. The strontium unit levels increased in milk immediately following contamination of the farm with fallout debris, and then decreased with time as well as the amount of $\mathrm{Sr}$ associated with the cattle's diet.

Observations during the past decade indicate that less than 10 per cent of the total Sr produced from nuclear detonations at Nevada Test Site has been deposited within 200 miles from the point of detonation. 
SUMMARY STATEMENT OF FINDINGS RELATED TO THE DISTRIBUTION, CHARACIERISTICS, AND BIOLOGICAI AVAILABILITY OF FAILOUT DEBRIS ORIGINATING FROM TESTING PROGRAMS AT THE NEVADA TEST SITE (*)

\section{INTRODUCTION}

During the past decade the Environmental Radiation Division has been involved in progressively intensified programs designed to answer one principal question, viz., "How much man-made radioactivity distributed in the environment can be tolerated safely by man and his economy?"

The more specific objectives of our effort within this broad context include:

(a) Delineation of fallout patterns and their characteristics with respect to particle size in order to define the mechanics of fallout more accurately. This, in turn, leads to a comparison of the effects of the yield of the detonated device, the type of device support, and the geometric relation between the detonation and ground surface on the resultant fallout debris deposited within the fallout pattern.

(b) A detailed study of the chemical, physical and radiological characteristics of fallout debris relative to its particle size and occurrence within the fallout pattern.

(c) Determination of the biological availability, rate of accumulation, and retention of the fallout debris for various native and domestic plants and animals, as well as the persistence and redistribution of residual contamination in the total environment. FALLOUT PHEWOMENOLOGY AND ITS CHARACTERISTICS

Fallout from test devices detonated at Nevada Test Site is governed by many complex variables such as: (a) energy yield, (b) wind structure, (c) support used for the detonation of devices, (d) nature of ground surface, (e) degree of fireball intersect with ground surface, ( $f$ ) mass of inert material surrounding the device. Data presenting the resultant deposition and characteristics of fallout from various detonation studied by this laboratory are summarized in the following statements.

(*) Presented as testimony during the Hearings on "Biological and Environmental Effects of Nuclear War" before the Special Subcomittee on Radiation of the Joint Committee on Atomic Energy, Congress of the United States; June 22-26, 1959. 
?age 6

1. Characterlstics of Fallout Patterns: The coordination of aerial survey measurements of fallout patterns with sround survey meter measurements has greatly increased the detall and accurecy of fallout pattern dellneation as well as the distances to which fallout patterns can be extended from the point of detonation.

By use of aerial survey equipment and techniques as developed by the U. S. Geological Survey, fallont radiation intensities within an area of approximately 10,000 square miles were measured in about 12 hours by one a1rcraft. Aerial measurements agreed within \pm 10 per cent of measurements taken 3 feet above the ground by conventional survey neters. During the Plumbbob Test Series, (1957) fallout petterns were routinely measured to listances of 200 to $300 \mathrm{mlles}$ from Ground Zero; however, one fallout pattern from a tower-supported detonation was documented as far as 700 miles from the Nevada Test Site with the radiation levels readily detectable at that distance (Figs. 1, 2, and 3) (1).

The detalled documentation of fallout patterns during the Pluabbob Series (1957) afforded the opportunity to conflrm the existence of "hot spots" in most fallout patterns. "Hot spots" vere first identified in 1948 when the fallout pattern of the Irinity detonation Nev Nexico had been outlined in detall (2).

It is the opinion of the authors that terrain features such as mountain ridges create a sigaiflcant turbulence in the radioactive dust cloud as it mores over the ridge causing an increased amount of fallout to occur on the leeward side. Examples of this are illuatrated in the patterns of Shot Diablo (F1g. 1) and Shot Smoly (F1g. 2) of the PIwibbob Series. Rainouts have also been reported to be responsible for hot spots" within 300 miles of lievada Test Site; hoverer, the docunented "hot spots" referred to by this Laboratory oceurred in areas in vhich no precipitation occurred during fallout.

While the occurrence of "hot spots" has been associated with prominent terrain features in many cases, data are lasufficient to fully explain their mechanism of formation and to permit their prediction. Nevertheless, the radiation intensity contours of fallont patterns in general have been quite accurately predicted as 1llustrated by the 


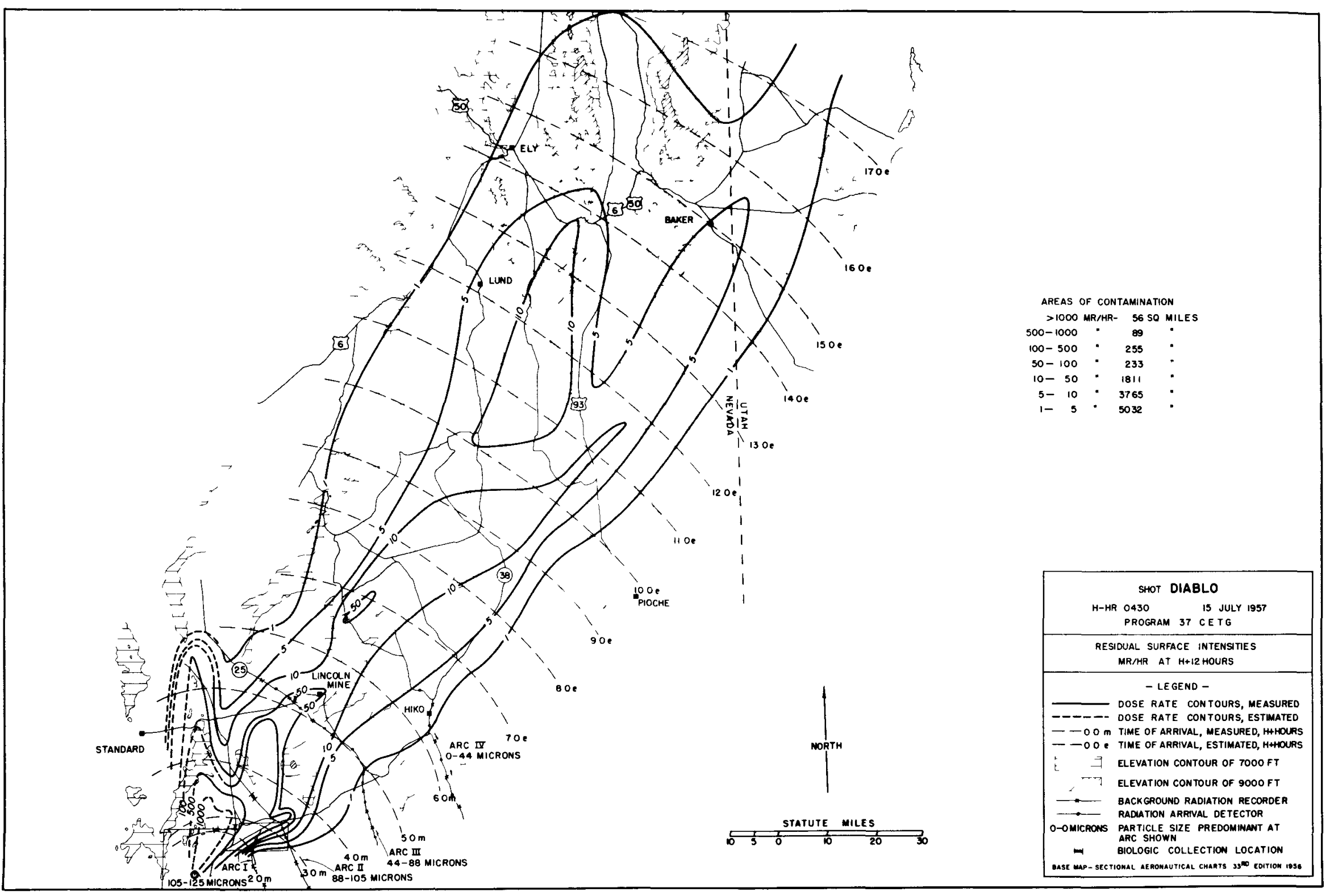

FIG I SHOT DIABLO FALLOUT PATTERN 




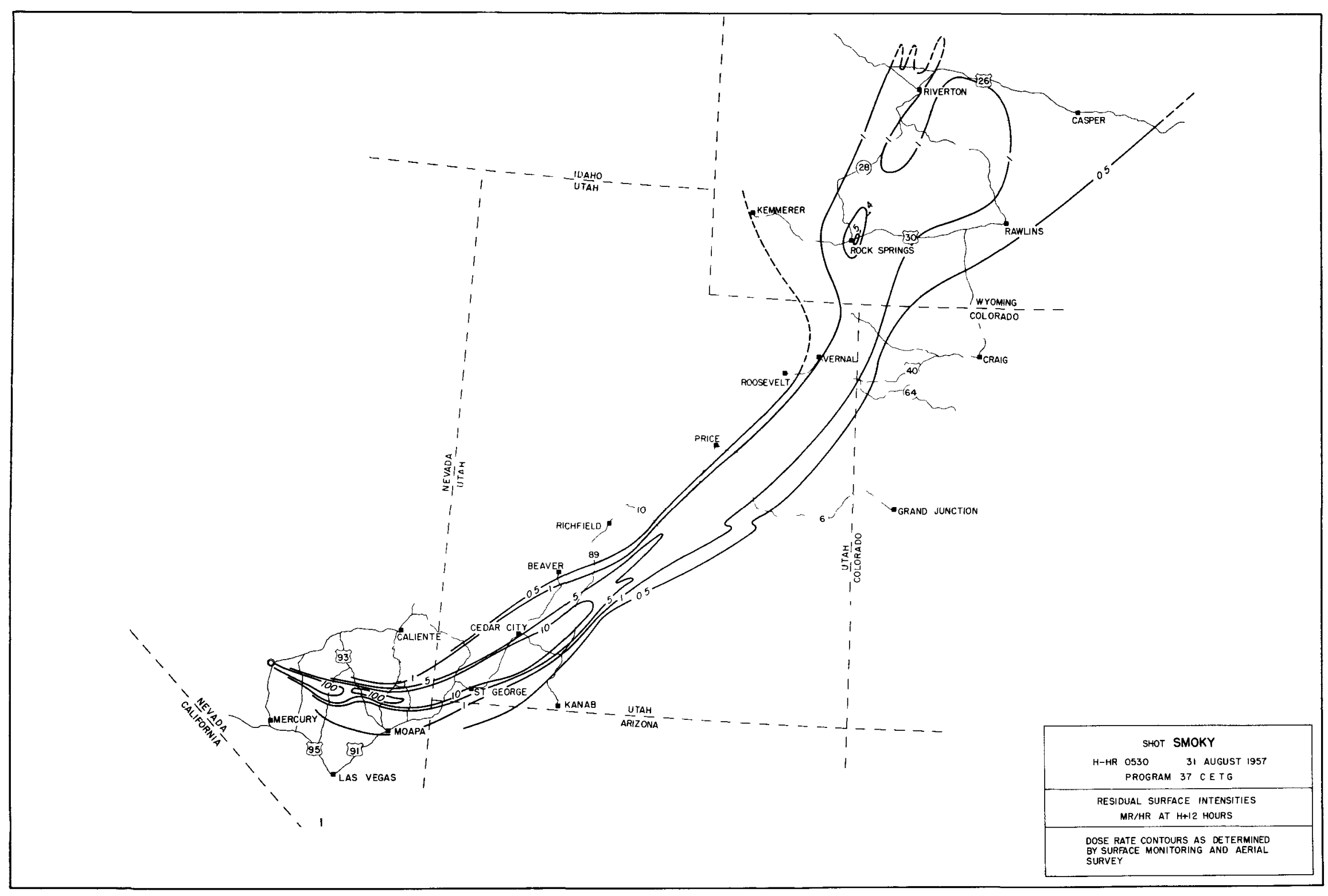

FIG. 3 SHOT SMOKY EXTENDED FALLOUT PATTERN 
Weather Bureau prediction and the measured pattern of Shot Smoky (Fig. 4 ). It should be noted that quite radical deviations from "idealized" fallout patterns may result from local meteorological conditions; the pattern of Plumbbob Series Shot Wilson (Fig. 5) illustrates the effect of widely divergent wind directions of different air strata at the time of detonation.

2. 'Iocal' Fallout Rainout Intensity Levels: Fallout from aerial bursts has not been detectable by conventional ground survey methods within 200 miles of Ground Zero (3). Two test devices detonated from balloons at 1500 feet without the fireball intersecting the ground surface deposited less than 0.2 per cent of the theoretical fallout radioactivity ${ }^{\perp}$. The area measured is defined in this case by the $0.1 \mathrm{mr} / \mathrm{hr}$ radiation intensity contour (at $\mathrm{H}+12 \mathrm{hrs}$ ) between the distance of $I$ mile from Ground Zero and the distance corresponding to a fallout time of $\mathrm{H}+12 \mathrm{hrs}$. To illustrate the effect of the intersection of fireball, a balloon-supported shot which did intersect the ground surface deposited 2.12 per cent of the theoretical fallout within the $1 \mathrm{mr} / \mathrm{hr}$ contour to $\mathrm{H}+12 \mathrm{hr}$ fallout time. However, fallout originating from test devices mounted on steel towers whose fireballs in some cases intersected the ground surface, and in other cases did not, deposited 6.7 to 24.5 per cent of the theoretical fallout radioactivity within the same area limits (1).

3. Particle Size Distribution in Fallout Patterns: The size of fallout particles decreased with greater distance from Ground Zero. Also, the size of fallout particles decreased with greater lateral distance from the line of maximum radiation intensity along a fallout pattern or "midline" of fallout $(1,3,4)$. The relative amount of radioactivity associated with particle sizes less than 44 microns in diameter was increased by decreasing the mass of device support and cab materials; therefore, the amount of fallout occurring at greater distances from Ground Zero in this particle size range increased (1).

The theoretical fallout is calculated on the basis of 300 gamma megacuries at $\mathrm{H}+\mathrm{I}$ hr per kt yield. 


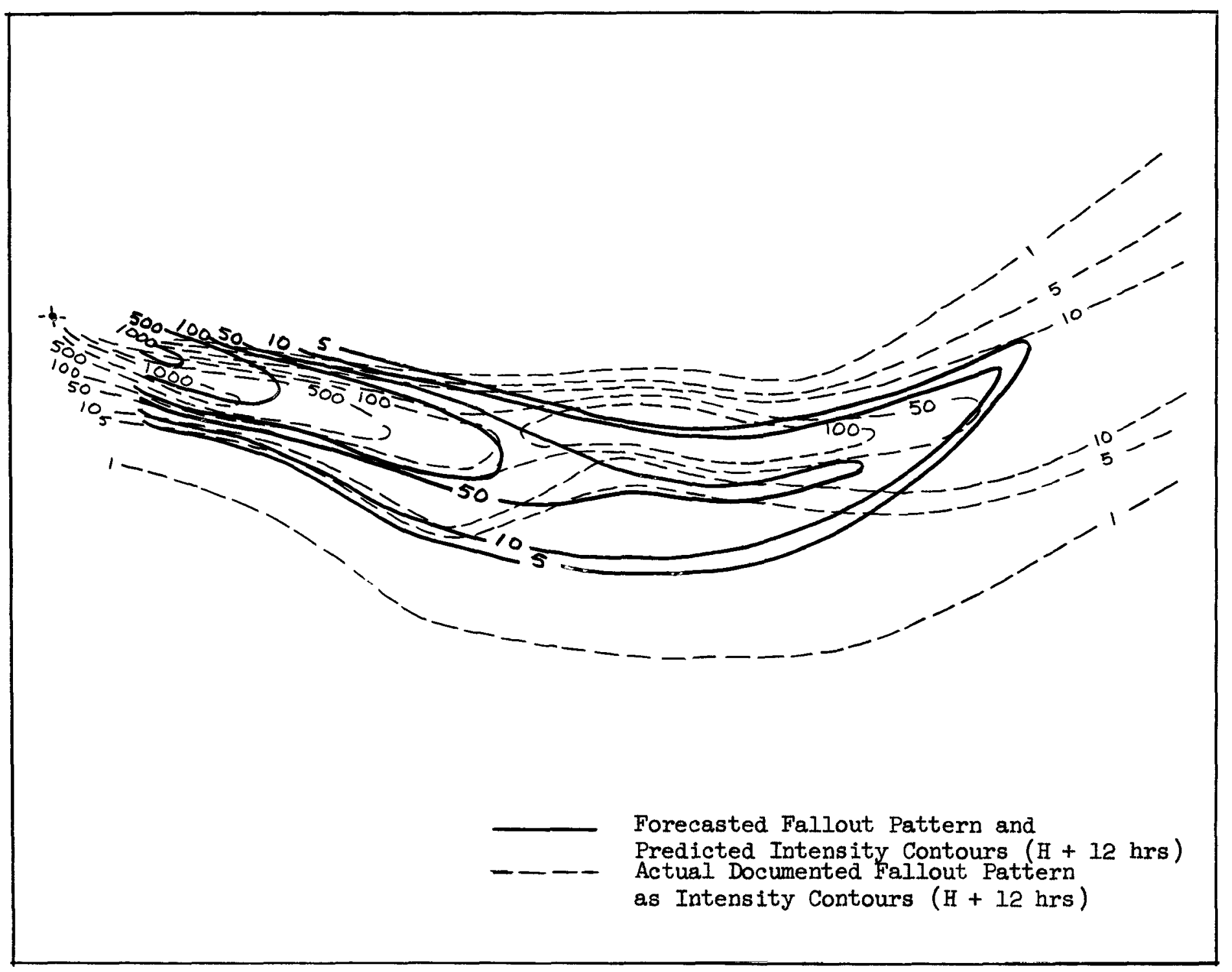

FIg. 4 COMPARISON OF FORECAST TO ACTUAL SHOT SMOKY FALLOUT PATTERNS 


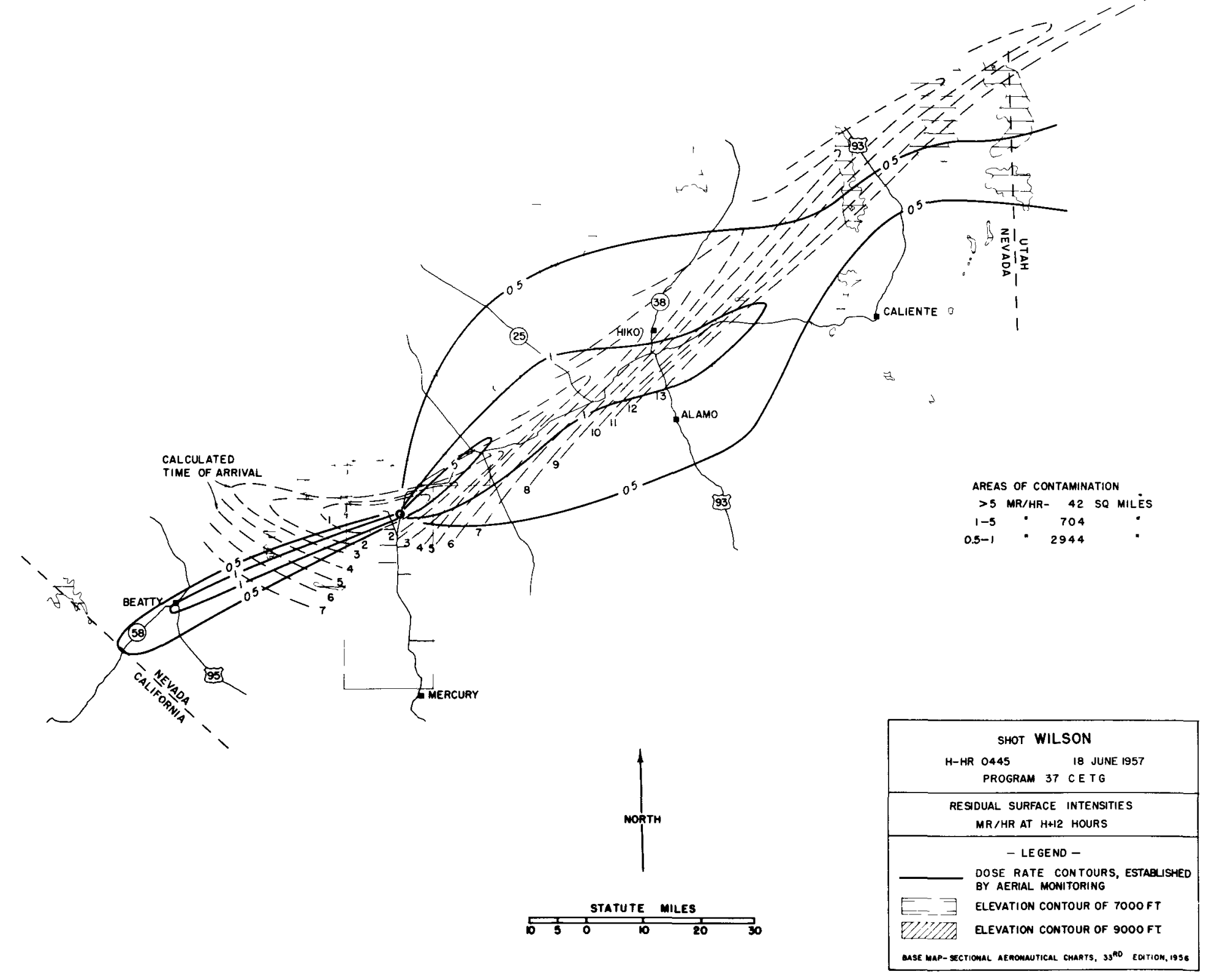

FIG 5 SHOT WILSON FALLOUT PATTERN 
It was found that vegetation in the environs of Nevada Test Site during the Teapot Series (1955) retained predominately less than 44 micron fallout particles (5). Therefore, this size range has been emphasized in our recent studies.

Within the limits of 1 mile from Ground Zero out to a distance corresponding to $\mathrm{H}+12 \mathrm{hr}$ fallout time, test devices detonated on 500 and 700-foot towers produced approximately 30 per cent of the fallout radioactivity in the particle size range less than 44 microns in diameter. However, a test device of nearly comparable kt yield mounted on a 700 -foot balloon produced 70 per cent of the fallout radioactivity in the less than 44 micron particle size range.

Within the less than 44 micron diameter particle size range samples, it was found that from 38 to 50 per cent of the radioactivity was associated with particles less than 5 microns in diameter in fallout samples from tower-supported detonations; from 51 to 83 per cent of the radioactivity was associated with the less than 5 micron diameter particles from balloon-supported detonations. Significant percentage contributions of radioactivity by particles less than 5 microns in diameter were observed at virtually all sampling locations for both tower and balloonsupported detonations (1).

4. Radiochemical Properties of Fallout Debris (1): Fallout particles less than 44 microns in diameter had greater percentages of Sr89, 90 and Ru103, 106 at 30 days after detonation than did the larger sized particles. The percentage of Sr89, 90 and Ru103, 106 in balloon-supported detonation fallout debris was from 2 to 4 times higher than it was in corresponding particle sizes from tower-supported detonations. The reverse was observed for $\mathrm{Zr}-95$. Bal40, Ce-141, 144 and Y-9l varied to a lesser degree between fallout from tower and balloonsupported detonations. Strontium9o averaged 2.7 per cent of the total radiostrontium at $D+30$ days in fallout originating from detonations supported by towers.

The percentage concentration $(D+30$ days $)$ of radioisotopes of $\mathrm{Ba}-140, \mathrm{Ce}-141,144, \mathrm{Ru}-103,106, \mathrm{Sr}-89,90, \mathrm{Y}-91$ and $\mathrm{Zr}-95$ in different fallout particle size fractions from tower- and balloon-supported 
Page 14

detonations is illustrated in Fig. 6. The average values expressed as per cent of the total activity from the primary contributing isotope (s) at $D+30$ days are sumarized in Table 1 .

TABLE 1

Average Contributions of Radiolsotopes to Total Beta Activity in Fallout Debris Originating from Tower-and Balloon-Supported Detonations

\begin{tabular}{lccc}
\hline & \multicolumn{3}{c}{ Average Per Cent of Total Beta Activity at D + 30 Days } \\
\cline { 2 - 4 } Isotope & Tower Support & Balloon Support & $\begin{array}{c}\text { Theoret1cal U235 } \\
\text { Fiss ion Products }\end{array}$ \\
\hline Bal40 & 13.7 & 17.9 & 10.49 \\
Ce141, 144 & 17.6 & 14.3 & 13.10 \\
Ru103, 106 & 2.6 & 9.2 & 5.99 \\
Sr89 & 1.83 & 4.3 & 6.00 \\
Sr90 & 0.05 &.-- & 0.08 \\
Y91 & 10.4 & 14.0 & 7.74 \\
Zr95 & 7.8 & 3.93 & 8.13 \\
\hline
\end{tabular}

*Bolles and Ballou USNRDL- 456

5. Solubility of Fallout Debris: Solubility of fallout debris is one of the most important properties to consider with respect to the "internal emitter" problem in blological systems. The solubility of radioactive fallout debris in water and in $0.1 \mathrm{~N}$ hydrochloric acid (HCI) has been used arbitrarily as indices of biological availability.

The radioactivity in fallout debris from tower-supported detonations has been observed to be from 1 to 2 per cent soluble in water (16). Fallout debris from balloon-supported detonations was more soluble in both water and 0.1 N HCl than that produced by other types of detonations (1). The solubility of fallout debris from tower-supported detonations increased with decreasing particle size; however, in the case of balloonsupported detonations, the smaller sized particles vere somewhat less 


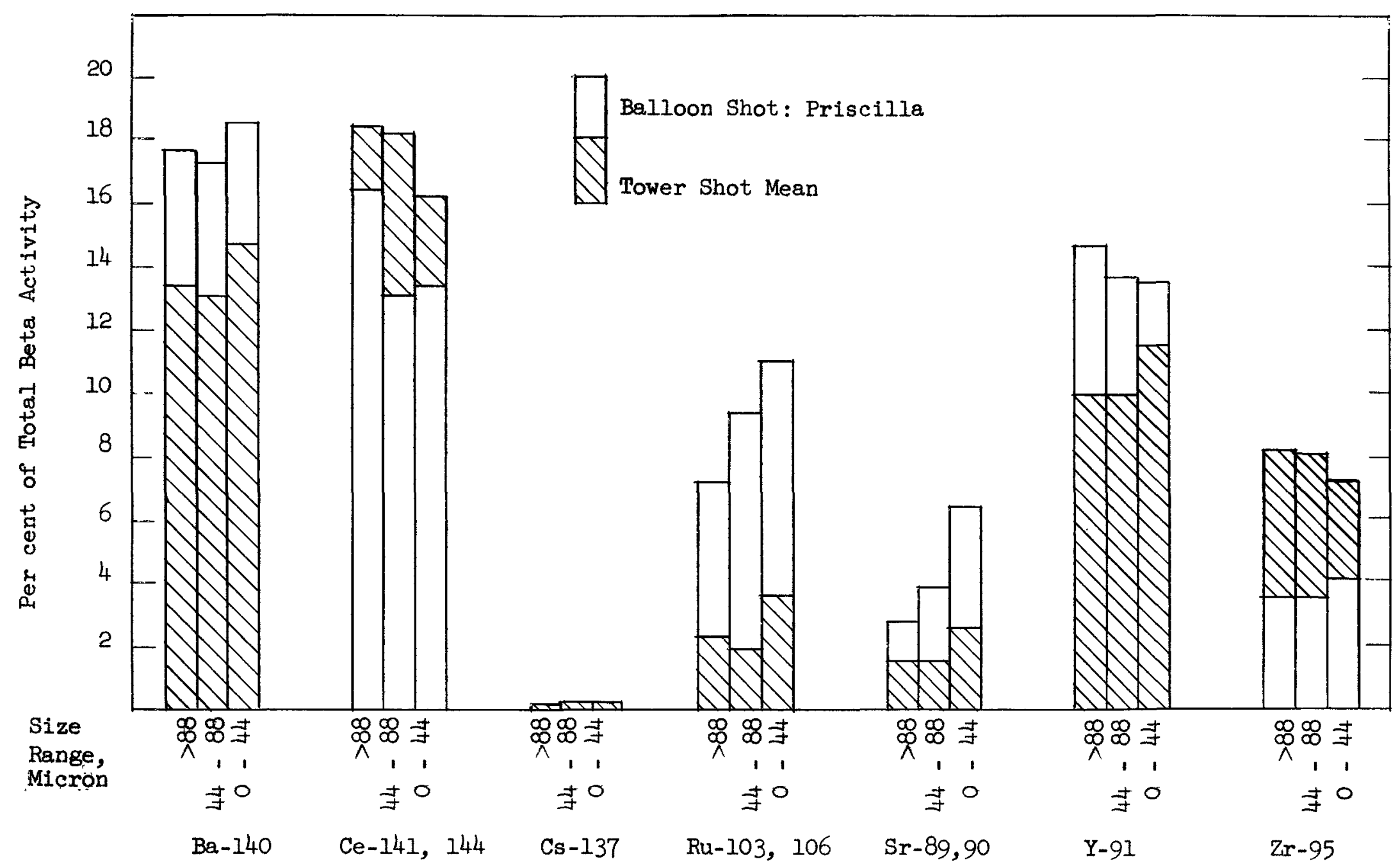

Fig. 6 Comparison of Radioelement Percentages of Different Particle Size Fractions of Tower and Balloon Shot Fallout 
soluble than larger particles (Table 2).

TABLE 2

Solubility in Water and $0.1 \mathrm{~N} \mathrm{HCl}$ of Fallout Debris from Tower and Balloon-Supported Detonations

\begin{tabular}{lccc} 
Support & $\begin{array}{r}\text { Particle Size } \\
\text { Range (Micron) }\end{array}$ & $\frac{\text { Solubility }}{\text { Water }}$ & 0.1 Per cent of $\beta$ Activity) \\
Tower & $>44$ & $<1$ & 5 \\
& $<44$ & $<2$ & 14 to 36 \\
Balloon & $>44$ & 31 & $>90$ \\
& $<44$ & 14 & $>60$ \\
\hline
\end{tabular}

The solubility of the 0 to 44 micron particle size fallout debris from the underground detonation, Jangle Series (1951), was intermediate to that observed from tower and balloon-supported detonations (5.4 per cent soluble in water, 25 per cent soluble in $0.1 \mathrm{~N} H C l$ ) (7).

6. Comparison of Properties of Fallout Debris from Balloon and Tower-Supported Detonations (1): A comparison of fallout debris from a balloon (Priscilla) and a tower-supported detonation (Smoky) having nearly similar kt yield and the same detonation height of 700 feet indicated that the amounts of water soluble Bal40 and Sr89, 90 deposited in the less than 44 micron particle size fraction within the 1 to $15-$ hour fallout time period were similar despite relatively large differences in the total amounts of radioactivity deposited in this particle size fraction.

The widespread distribution of the less than 44 micron particle size fraction from all types of devices detonated at the Nevada Test Site indicates that this particle size fraction is probably the most significant with respect to total area contaminated. Assuming that the soluble fractions of the fallout debris samples studied contain the same ratio of radioelements as is present in the original fallout debris, the 
application of this ratio to the per cent of the soluble activity yields the per cent of the various radioelements present in the 0.1 IN HCI and water-soluble extracts. Based on such calculations, the relative amounts of the several radioelements in the soluble fractions of equal quantities of less than 44 micron fallout debris from tower and balloon-supported detonations of similar yield and helght of detonation are presented in Fig. 7. It should be noted, however, that the deposition of less than 44 micron fallout debris from the tower-supported detonation considerably exceeded that from the balloon-supported detonation at different fallout times from 1 to 15 hours (Fig. 8).

The application of soluble radioelement percentages to the measured and the integrated radioactivities of the less than 44 micron particle size fractions from the two detonations gives an estimate of the relative amounts of the various radioelements deposited at different fallout times. As examples, the relative amounts of total acid-soluble and watersoluble Bal40 and Sr89, 90 derived from the less than 44 micron particle slze fraction deposited by the two detonations at various fallout times are 1llustrated in Figures 9 and 10. While the amounts of total and acidsoluble Bal40 and Sr89, 90 deposited by less than 44 micron fallout debris from the tower-mounted detonation were higher over the 1- to 15-hr fallout period, the amounts of water-soluble Bal40 and Sr89, 90 were similar.

7. Radioactive Decay of Fallout Debris (1): Fallout debris from a specific detonation during the Plumbbob Series had similar beta decay curves regardless of particle size and time of fallout. Beta decay curves of most detonations approximated the $\mathrm{T}^{-1.2}$ decay relationship over a perlod of $\mathrm{H}+12$ to $\mathrm{H}+6,000 \mathrm{hrs}$. However, slopes of the order of $\mathrm{T}^{-1.4}$ occurred from $\mathrm{H}+6,000$ to $\mathrm{H}+10,000 \mathrm{hrs}$.

Decay curves of the gama emmission rate were different from those of beta decay for fallout debris from a specific detonation. Gamma decay curves of fallout debris from different detonations were generally similar, but more variable than corresponding beta decay curves.

Plumbbob beta and gamma decay curves, derived from measurements of fallout samples from seven detonations, are illustrated in Fig. Il in relation to the $T^{-1.2}$ decay curve and a theoretical mixed fission product 


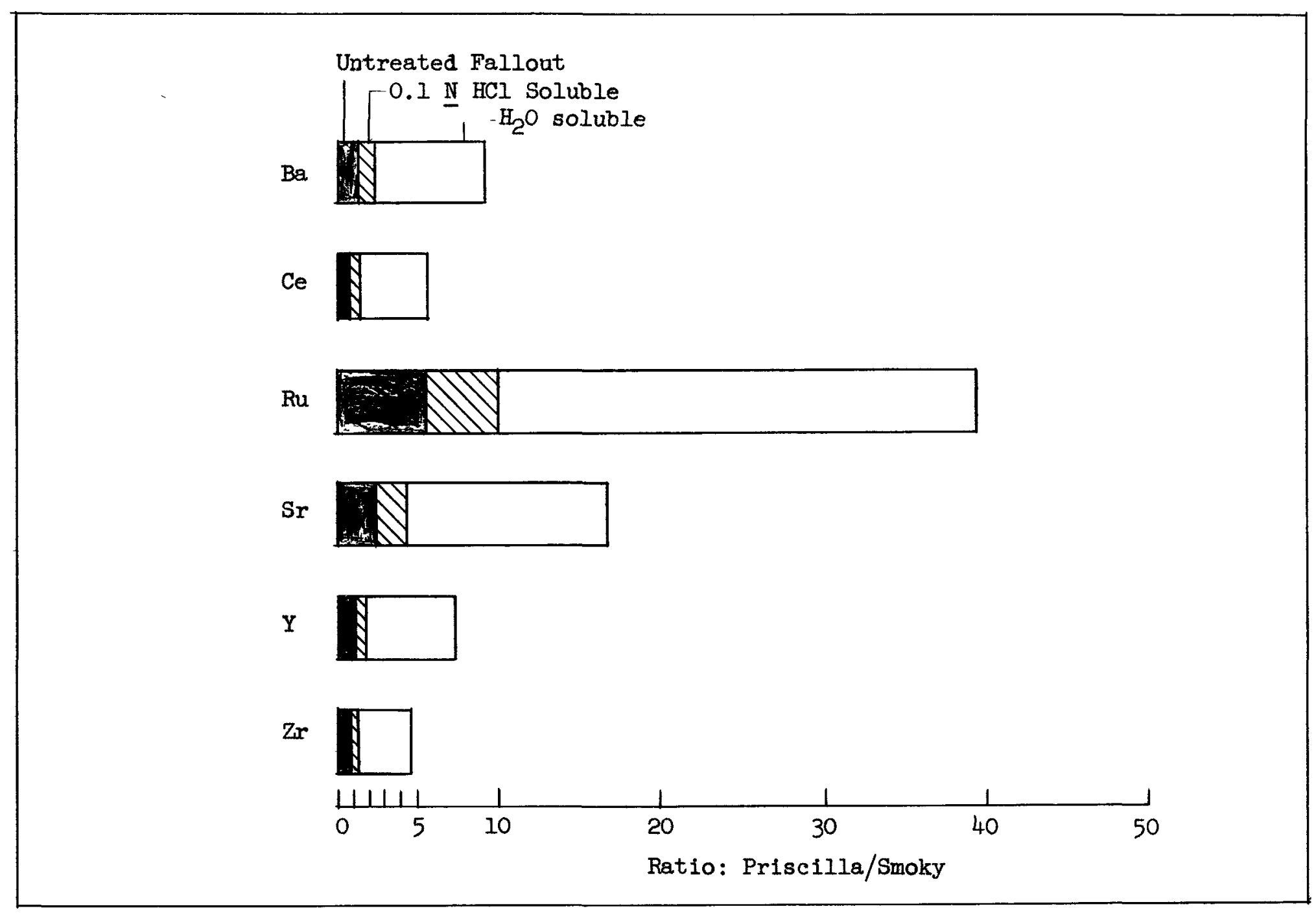

Fig. 7 Calculated Priscilla/Smoky D + 30 Day Radioelement Ratios in Untreated, Acid-Soluble, and Water-Soluble Fractions of 0 - 44 micron Fallout Particles 


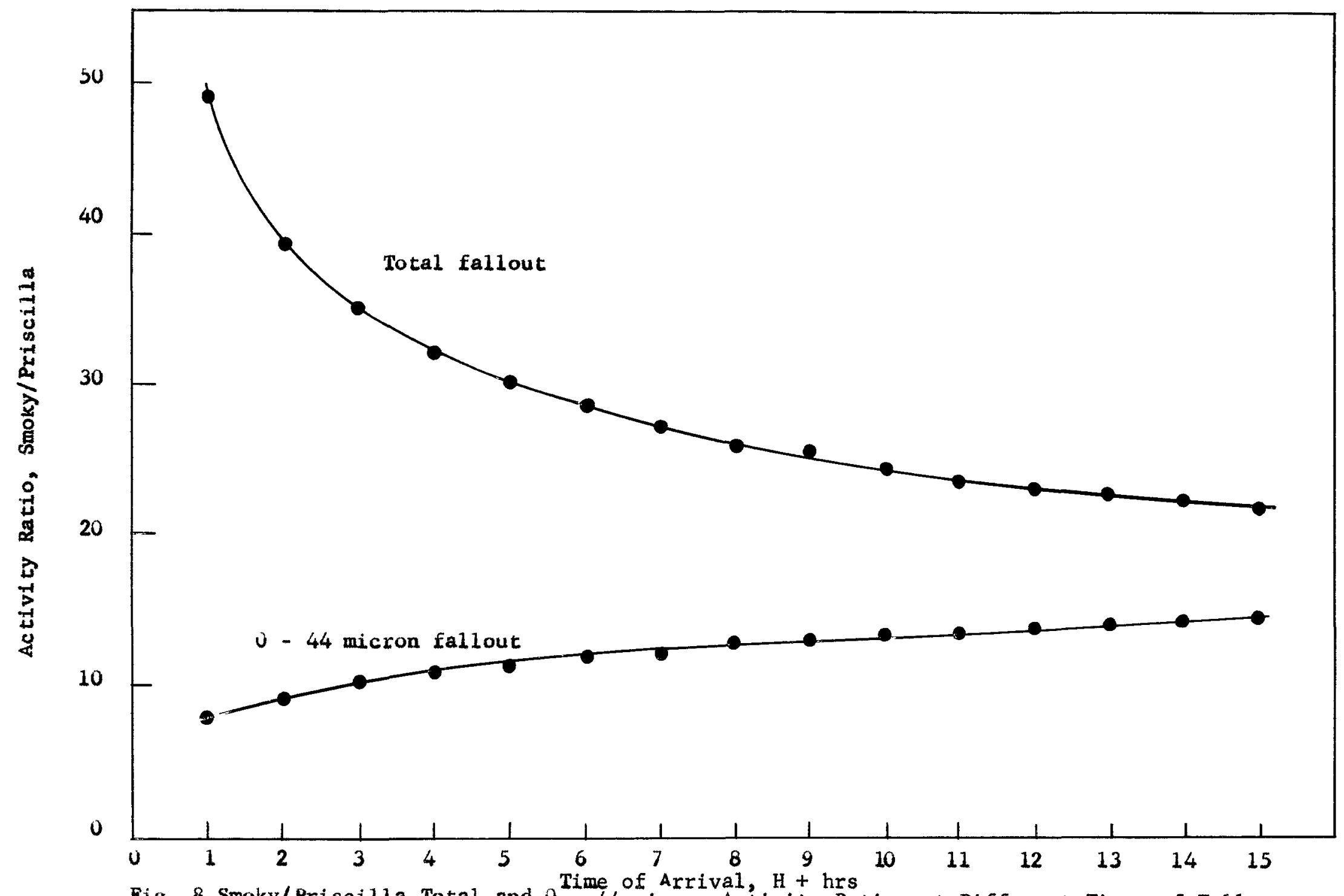

Fig. 8 Smoky/Priscilla Total and 0 Time of Arrival, $4+4$ micron Activity Ratios at Different Times of Fallout Arrival 


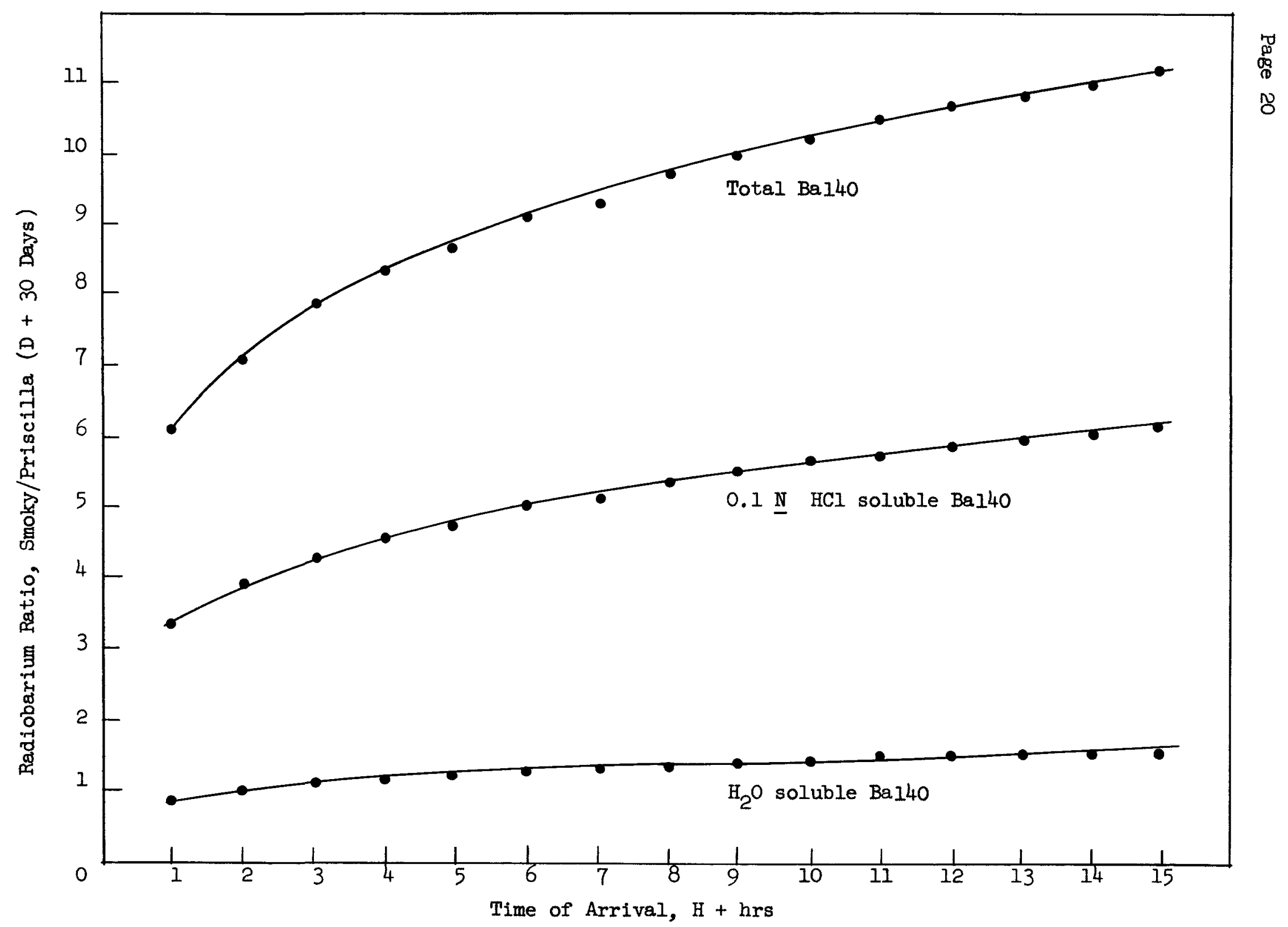

Fig. 9 Calculated Smoky/Priscilla Total, Acld-soluble, and Water-soluble 0 - 44 micron Fallout Debris Radiobarium Ratios at Different Times of Fallout Arrival 


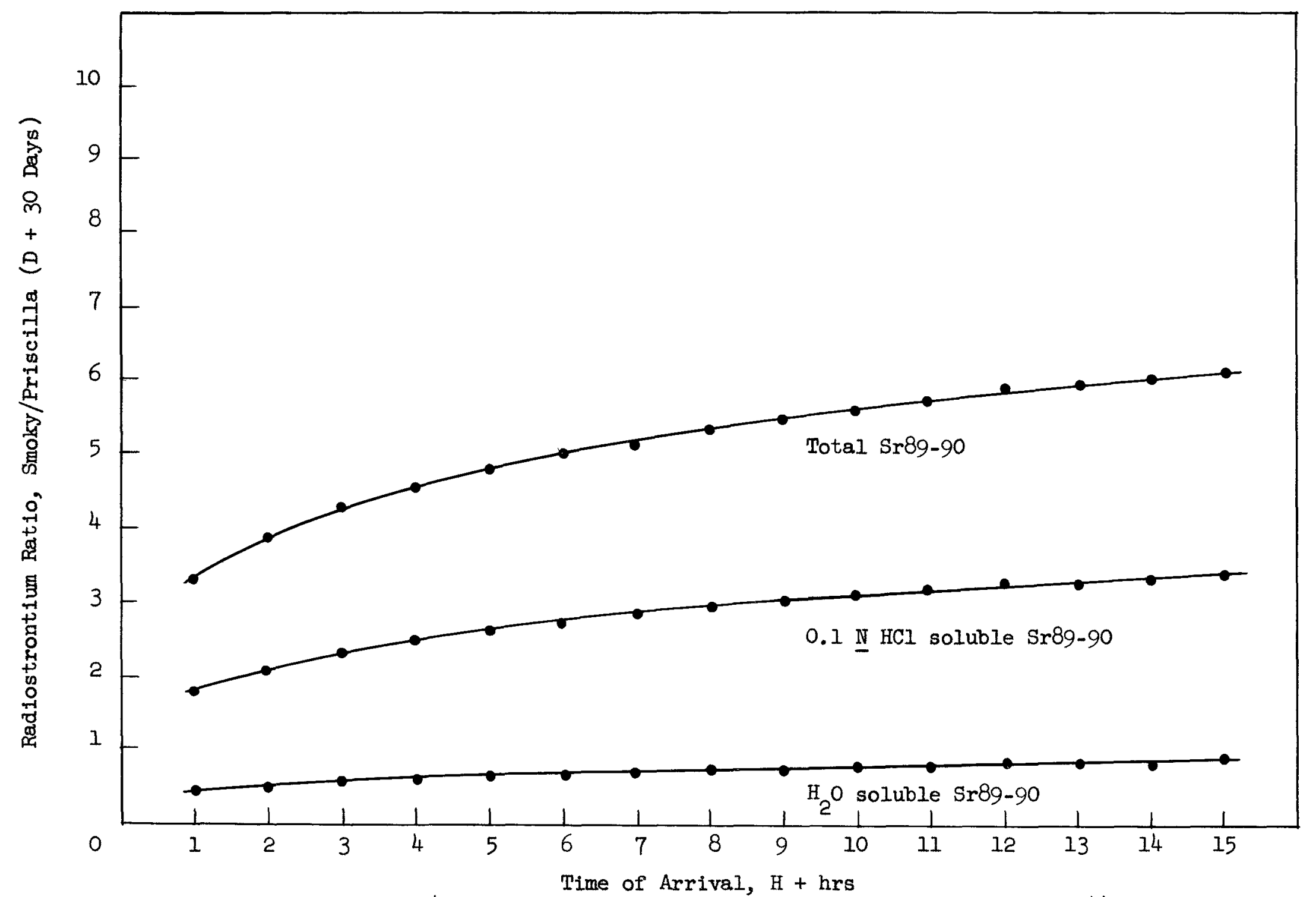

Fig. 10 Calculated Smoky/Priscilla Potal, Acid-soluble, and Water-soluble 0 - 44 micron Fallout Radiostrontium Ratios at Different Times of Fallout Arrival 
(U235) decay curve.

Estimates of dosage in fallout areas have generally been based, in part, on a decline of dose-rate $(\mathrm{mr} / \mathrm{hr})$ with time according to the $\mathrm{T}^{-1.2}$ relationship. A dose-rate decline with time according to the $\mathrm{Plumbbob}$ gamma decay (PGD) curve yields calculated doses which are 1.5 to 2 times greater than those calculated by the $\mathrm{T}^{-1.2}$ relationship for different fallout times out to approximately 400 days after detonation (Table 3).

\section{TABLE 3}

Comparison of Radioactivity Dose to 10,000 Hrs Calculated on the Basis of Plumbbob Gamma Decay Curve and $T^{-1.2}$ Relationship (Using $100 \mathrm{mr} / \mathrm{hr}$ Intensity at Time of Arrival for Illustration)

$\begin{array}{cccc}\text { Time of } & \text { Dose to 10,000 hrs } & \text { Dose to } 10,000 \text { hrs } & \\ \text { Arrival } & \text { Using PGD Curve } & \text { Using T-1.2 } & \text { Ratio of PGD } \\ \text { (hr) } & (\mathrm{mr}) & (\mathrm{mr}) & \text { Dose to } \mathrm{T}^{-1.2} \text { Dose }\end{array}$

$\begin{array}{lrrr}H+2 & 1,638 & 818 & 2.00 \\ H+4 & 2,635 & 1,582 & 1.67 \\ H+6 & 3,993 & 2,319 & 1.72 \\ H+8 & 4,979 & 3,041 & 1.64 \\ H+10 & 5,917 & 3,744 & 1.58 \\ H+12 & 6,679 & 4,437 & 1.51\end{array}$

8. Deposition of Radiostrontium in Areas Adjacent to Nevada Test Site (1): Approximately 0.13 per cent of the total amount of Sr89 produced by a balloon-supported detonation whose fireball intersected the ground surface was deposited within the fallout time of arrival of $\mathrm{H}+12 \mathrm{hrs}$. On the other hand, only 0.004 and 0.008 per cent of the total Sr89 produced was deposited within $\mathrm{H}+12 \mathrm{hrs}$ fallout time by two balloon-supported detonations whose fireballs did not intersect the ground. Tower-supported detonations deposited from 0.5 to 2 per cent of the Sr89 produced and from 1.6 to 7.2 per cent of the total Sr90 produced ${ }^{2}$ within $H+12$ hrs fallout time. Calculations were based on the results of analyses of fallout debris The theoretical potential Sr89 and Sr90 fallout is based on the production of 1 gram or 27,700 curies of $5 r 89$ and 1.14 gram or 146 curies of $5 r 90$ per kt yield. 
FIG. II COMPARISON OF MEASURED PLUMBBOB BETA AND GAMMA, $T^{-1.2}$, AND THEORETICAL DECAY CURVES.

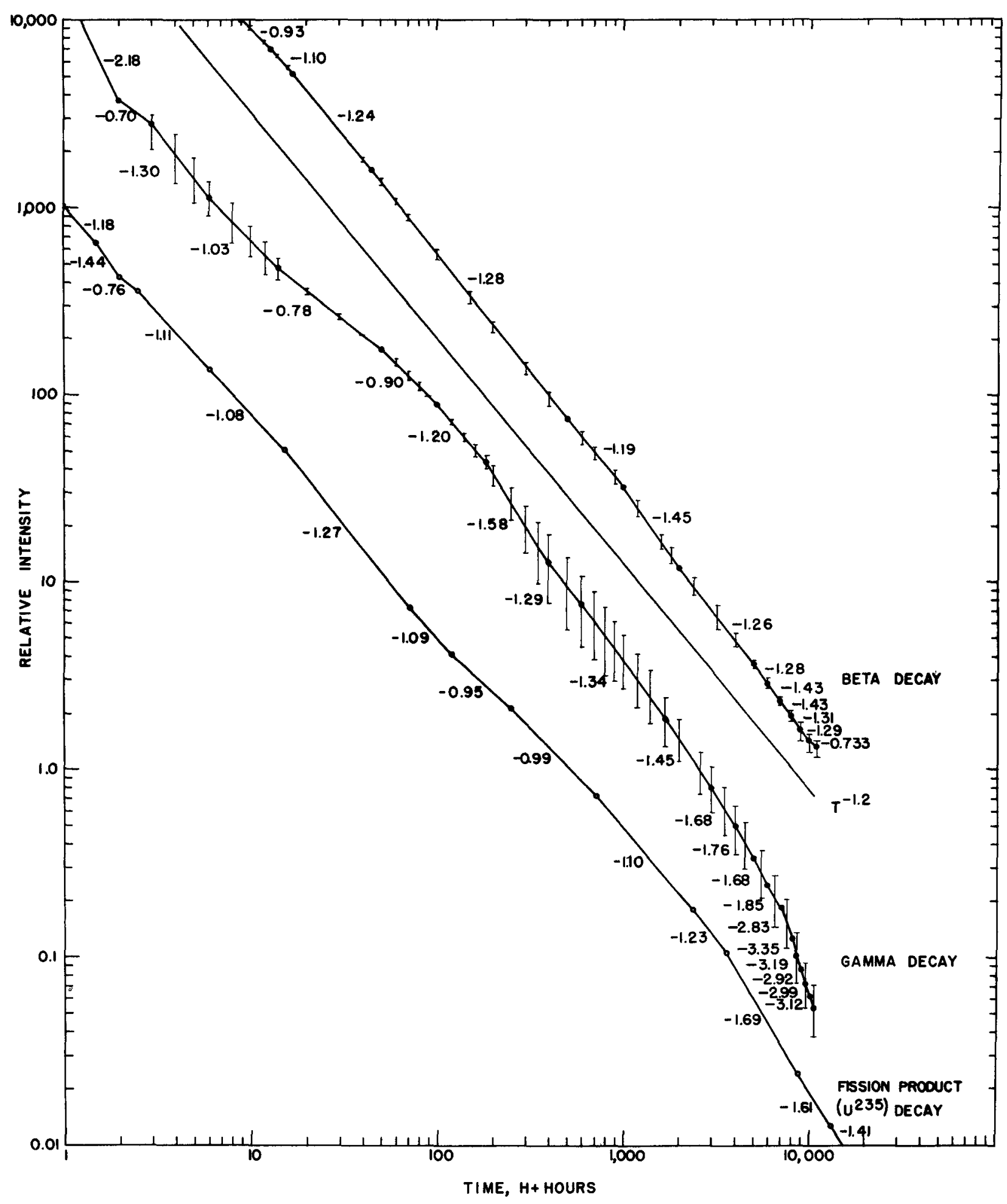


Page 24

samples for $\mathrm{Sr} 89$ and $\mathrm{Sr} 90$ and integrated fallout radiation intensities converted to curies by ratios of $\mu \mathrm{c} / \mathrm{ft}^{2}$ and $\mathrm{mr} / \mathrm{hr}$. The analys is of balloon detonation fallout debris for Sr90 was not performed.

The tower shot percentage deposition of Sr89 was less than that of Sr90 out to distances corresponding to $\mathrm{H}+12 \mathrm{hr}$ fallout arrival time. This is attributed to relatively low percentages of $5 r 89$ in larger fallout particle size fractions which generally represent the majority of the fallout radioactivity in areas close to Ground Zero. This fractionation of Sr89 and Sr90 with respect to particle size may be predicted on the basis of the different half-lives of their noble gas precursors, Kr89 and $\mathrm{Kr} 90$, respectively, and the rate of particle formation.

BIOLOGICAL AVAILABIITTY AS RELATED TO THE FATE AND PERSISTENCE OF FALLOUT DEBRIS IN FALLOUT PATTERNS OUT TO 400 MILES FROM NEVADA TEST SITE

1. Distribution and Redistribution of Fallout Debris in Soils: In undisturbed areas the radioactive debris from fallout was confined to the surface 2 inches of the soil profile even after 9 years following fallout contamination (Trinity Areas, New Mexico) (8). In agricultural areas under cultivation, the distribution of fallout radioactivity was found down to depths of 4 to 8 inches due to plowing, harrowing, etc. Soil leaching experiments preformed in the Iaboratory using the equivalent of 84 inches of water translocated the surface deposited radioactivity only about 0.5 inch into the soil.

Surface-deposited fallout debris tends to become mechanically trapped in the soil. Natural disturbance by wind action causes minor amounts of the total fallout debris deposited in various areas studied to be redistributed within the fallout pattern from the point of original deposition. Fallout particles 44 to 88 microns in diameter contributed an average of 9.7 per cent of the total redistributed fallout debris following the Priscilla (balloon) detonation as compared to 21.0 per cent following the Smoky (tower) detonation of the Plumbbob Test Series. Particles less than 44 microns in diameter contributed an average of 85.8 per cent of the radioactivity deposited from the Priscilla detonation as compared to 68.3 per cent from the Smoky detonation (1). 
2. Sr90 Contamination Levels in Nevada and Utah Soils (10): Strontium 90 levels of the surface 0 to 1 inch depth soil samples collected in Nevada and Utah in August, 1958, ranged from 31.9 to $142 \mathrm{mc} / \mathrm{sq}$ mile in virgin areas near known fallout intensity midlines and from 7.5 to 22.7 $\mathrm{mc} / \mathrm{sq}$ in agricultural areas which did not necessarily coincide with fallout midlines.

The Sr90 contamination level in cultivated 0 to $I$ inch surface soil samples was lower than that of virgin area samples (Table 4 ) probably as a result of both reduced contamination by fallout debris from Nevada Test Site activities and subsequent cultivation of the soll. The observed Sr90 levels in agricultural area samples were similar to those reported for other areas of the country; however, the comparative levels of Sr90 in the subsoil are not known.

The assumption that Nevada Test Site activities represent the major source of Sr90 contamination in the virgin area locations is supported by Sr90 percentages of mixed fission product beta activity. The theoretical percentages for various Testing Series tended to be approached by the observed percentages (Table 5).

Four soll sampling sites were subjected to a comparative study of Sr90 contamination measured by total solubillzation following alkali fusion and by leaching with $6 \mathrm{~N} \mathrm{HCl}$. The results clearly indicate that in the Nevada - Utah area, total solubilization of soil samples is necessary in order to more accurately evaluate area contamination. The amounts of Sr90 leached by $6 \mathbb{N} \mathrm{HCl}$ varied within the range from 13 to 78 per cent of the total Sr90 present (Table 6).

TABLE 6

Comparison of Sr90 Levels in Nevada and Utah Soil Samples Determined by Alkall Fusion or $6 \underline{\mathrm{N}} \mathrm{HCl}$ Leaching

\begin{tabular}{lccc}
\hline & \multicolumn{2}{c}{ Sr90 Level (mc/sq mile) } & \\
\cline { 2 - 3 } Location & NaCO & Per cent Sr90 \\
Fusion & Leaching & Poluble in 6 N HCI \\
\hline Columbia, Utah & 67.2 & 52.8 & 78.6 \\
Enterprise, Utah & 41.2 & 7.6 & 18.5 \\
Moapa, Nevada & 142 & 18.6 & 13.1 \\
Panguitch, Utah & 31.9 & 16.2 & 50.7 \\
\hline
\end{tabular}


Page 26

TABLE 4

Sr90 Levels Measured by Fusion Analysis in Soll Samples Collected from Eleven Selected Areas in Nevada and Utah in August, 1958

\begin{tabular}{ccc} 
& \\
Area & Location & $\begin{array}{c}\text { Sr90 Activity } \\
(0 \text { to I" Depth) }\end{array}$ \\
\hline
\end{tabular}

Cultivated Agricultural Areas

$\begin{array}{llll}\text { Alamo, Nevada } & 1 \mathrm{mi} \mathrm{S} & 21.3 & 6.8 \\ \text { Moapa, Nevada } & 7.7 \mathrm{mi} \mathrm{NW} & 16.3 & 2.5 \\ \text { Riverside, Nevada } & 0.4 \mathrm{mi} \mathrm{s} & 22.7 & 9.6 \\ \text { St. George, Utah } & 1 \mathrm{mi} \mathrm{SE} & 14.4^{*} & 4.5 \\ \text { Hurricane, Utah } & 1 \mathrm{mi} \mathrm{SW} & 12.4 & 3.5 \\ \text { Enterprise, Utah } & 0.7 \mathrm{mi} \mathrm{N} & 7.46 & 8.6 \\ \text { Cedar City, Utah } & 2 \mathrm{mi} \mathrm{SW} \mathrm{of} \mathrm{Enoch} & 16.7 & 4.6 \\ \text { Vernal, Utah } & 4 \mathrm{mi} \mathrm{S} & 13.8 & 8.7\end{array}$

Virgin Undisturbed Area, Fallout Midline Locations

$\begin{array}{llcc}\text { Moapa, Nevada } & 8 \mathrm{mi} \mathrm{N} & 142 & 38.3 \\ \text { Elgin, Nevada } & 3.8 \mathrm{mi} \mathrm{SW} & 114 & 140 \\ \text { St. George, Utah } & 5 \mathrm{mi} \mathrm{N} & 45.6 & 406 \\ \text { Enterprise, Utah } & 9 \mathrm{mi} \mathrm{N} & 41.2 & 51.2 \\ \text { Panguitch, Utah } & \begin{array}{l}\text { City Limit, NW } \\ \text { corner }\end{array} & 31.9 & 14.9 \\ \text { Sunnyside, Utah } & 3.1 \mathrm{mi} \mathrm{S} \mathrm{of} & 67.2 & 202 \\ & \text { Columbia, Utah } & & \end{array}$

* The Sr90 activity determined by fusion analysis in the $0-6$ " depth at this sampling location is $100 \mathrm{mc} / \mathrm{sq}$. mile. 
TABLE 5

Observed and Theoretical Sr90 Percentages of Mixed Fission Product Beta Activity in 0 to 1 " Surface Soil Samples from Locations on Midlines of Fallout Patterns

\begin{tabular}{|c|c|c|c|c|c|c|}
\hline \multirow[b]{2}{*}{ Area } & \multirow[b]{2}{*}{ Location } & \multirow{2}{*}{ 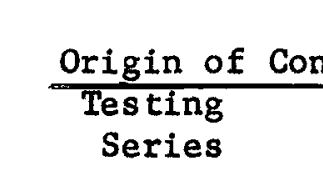 } & \multirow{2}{*}{ 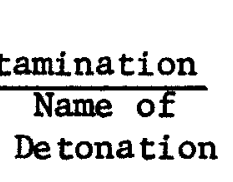 } & \multirow{2}{*}{$\begin{array}{c}\text { Area } \\
\text { Contamination } \\
(\mathrm{mc} / \mathrm{sq} \mathrm{mi})\end{array}$} & \multirow{2}{*}{$\begin{array}{l}\text { Sr90 Activity } \\
\text { (Per Cent of } \\
\text { Observed* }\end{array}$} & $\begin{array}{l}\text { as of Aug. } 1958 \\
\text { Total Activity) } \\
\text { Theoretical }\end{array}$ \\
\hline & & & & & & (for Series)** \\
\hline Moapa, Nevada & 8 miles $N$ & Upshot-Knothole & Simon & 142 & $12.2 \pm 3.18$ & $18-19$ \\
\hline St. George, Utah & 5 miles $N$ & Upshot-Knothole & Annie & 45.6 & $3.06 \pm 0.10$ & $18-19$ \\
\hline Elgin, Nevada & 3.8 miles SW & Teapot & Met & 114 & $6.77 \pm 1.15$ & $11-12$ \\
\hline Enterprise, Utah & 9 miles $N$ & Teapot & Met & 41.2 & $7.01 \pm 3.79$ & $11-12$ \\
\hline Panguitch, Utah & City Limit & P1 umbbob & Smoky & 31.9 & $2.38 \pm 0.30$ & $2-3.5$ \\
\hline Columbia, Utah & 3.1 miles $\mathrm{s}$ & P1 umbbob & Smoky & 67.2 & $2.57 \pm 0.38$ & $2-3.5$ \\
\hline
\end{tabular}

* Standard deviation values refer to variation of Sr90 percentages of 5 surface soil samples at each location.

** Determined from values published by Bolles and Ballou. USNRDL-456 
Page 28

3. Fallout Debris Contamination of Forage Plants:

Forage plants are recontaminated due to redistribution of small sized fallout particles. This provides a continuous source of internal emitters to grazing animals and a persistent low radiation fleld which is dependent on the changing proportions of medium- to long-lived fission products. During the Teapot (5) and Plumbbob (1) Test Series, it was found that the principal source of radioactive contamination on forage plants was from fallout particles in the less than 44 micron size fraction, 1.e., vegetation within fallout patterns out to 300 miles from Nevada Test Site was a

'selective' particulate collector. The number of fallout particles retained by the foliage is dependent upon its surface characteristics such as hairs, glands, and other mechanical traps. As much as 21.6 per cent of the radioactive contamination on plant follage was soluble in $0.1 \mathrm{~N} \mathrm{HCl,} \mathrm{which} \mathrm{sug-}$ gests that a similar percentage of the radioactivity in any fallout debris ingested might be available to animals (5).

The fallout debris contamination of native plant material persisted through the 18-day period following both Priscilla and Smoky detonations; the only change was that due to radioactive decay (1).

A very small fraction of the total contamination of the soil by fallout debris from tower-supported detonations was accumulated through the root systems of forage crops (within 300 miles of the Nevada Test Site) (5). Also, it was demonstrated that some fission products, primarily Sr89, were taken up by radish and Ladino clover plants grown in soll contaminated with fallout debris from the Jangle Series underground detonation (10).

4. Fission Product Accumulation by Native Animals:

During the 1955 Teapot Test Series, the concentration of radiolodine II31 in the thyroids of rabbits and other native rodents was found to be a function of distance. The maximum concentrations measured at approximately 60 miles from Ground Zero were from 2 to 7 times higher than those measured at 20 miles or at 160 miles (5). During the Plumbbob Series, between 82 and 87 per cent of the total radloactivity found in the thyroid tissue of the native rodents at $H+72$ hrs was radioiodine. Of this amount, 17 to 20 per cent was Iodinel31 and 65 to 67 per cent was Iodinel33. The maximum accumulation occurred at approximately $D+14$ days; samples taken at $D+20$ days 
contained only Iodinel31. Of the several fission products (Sr89-90, Y91, Ce144, Cs137, and Bal40) accumulated in bone, 12.5 to 40.0 per cent was accounted for as radiobarium and radiostrontium at $D+20$ days.

Maximum tissue accumulation of fission products occurred in samples of native animals collected at locations corresponding to fallout times of $\mathrm{H}+2$ to $\mathrm{H}+3 \mathrm{hrs}$. Fission product concentrations then decreased as the fallout time of arrival increased. For the single balloon-supported detonations studied, this decrease was constant between locations corresponding to $\mathrm{H}+2$ to $\mathrm{H}+12 \mathrm{hrs}$. For tower-supported detonations, however, the accumulated fission product concentration tended to be uniform over distances corresponding to fallout times of $H+5$ to $H+14$ hrs.

For any given sampling location, the relative tissue contents of the accumulated fission products from Priscilla and Smoky fallout debris were comparable; the maximum levels of accumulation occurred by $D+7$ days.

Biological "hot spots" were identified geographically in the Boltzmann (78 miles from Ground Zero), Diablo (60 miles from Ground Zero), Smoky (70 miles from Ground Zero), and Shasta (172 miles from Ground Zero) fallout patterns. The rate of decay of radioactivity in skin, G. I. tract, and muscle tissue samples collected from the field at the beginning of any particular study and the decline of radioactivity in these tissues serially sampled from the field population, was similar to the rate of radioactive decay of fallout debris. Liver and kidney tissue radioactivity levels showed similar decay characteristics but deviated markedly from the rate of radioactive decay of fallout debris. These relationships were not apparent for bone, which reflected the build-up and retention of specific isotopes.

The radioelement content of fack rabbit bone tissue was studied during the Plumbbob Test Series as a function of time of collection after fallout had occurred (Fig. 12). Bal40, Sr89 and Y9l concentration increased with time after fallout. These radioisotopes also were predominant contributors of the beta activity present in the bone. The presence of relatively high levels of Y9l was of particular interest; the predominant isotope presumably was the Y9l daughter product of the shortlived Sr9l precursor. 
Page 30

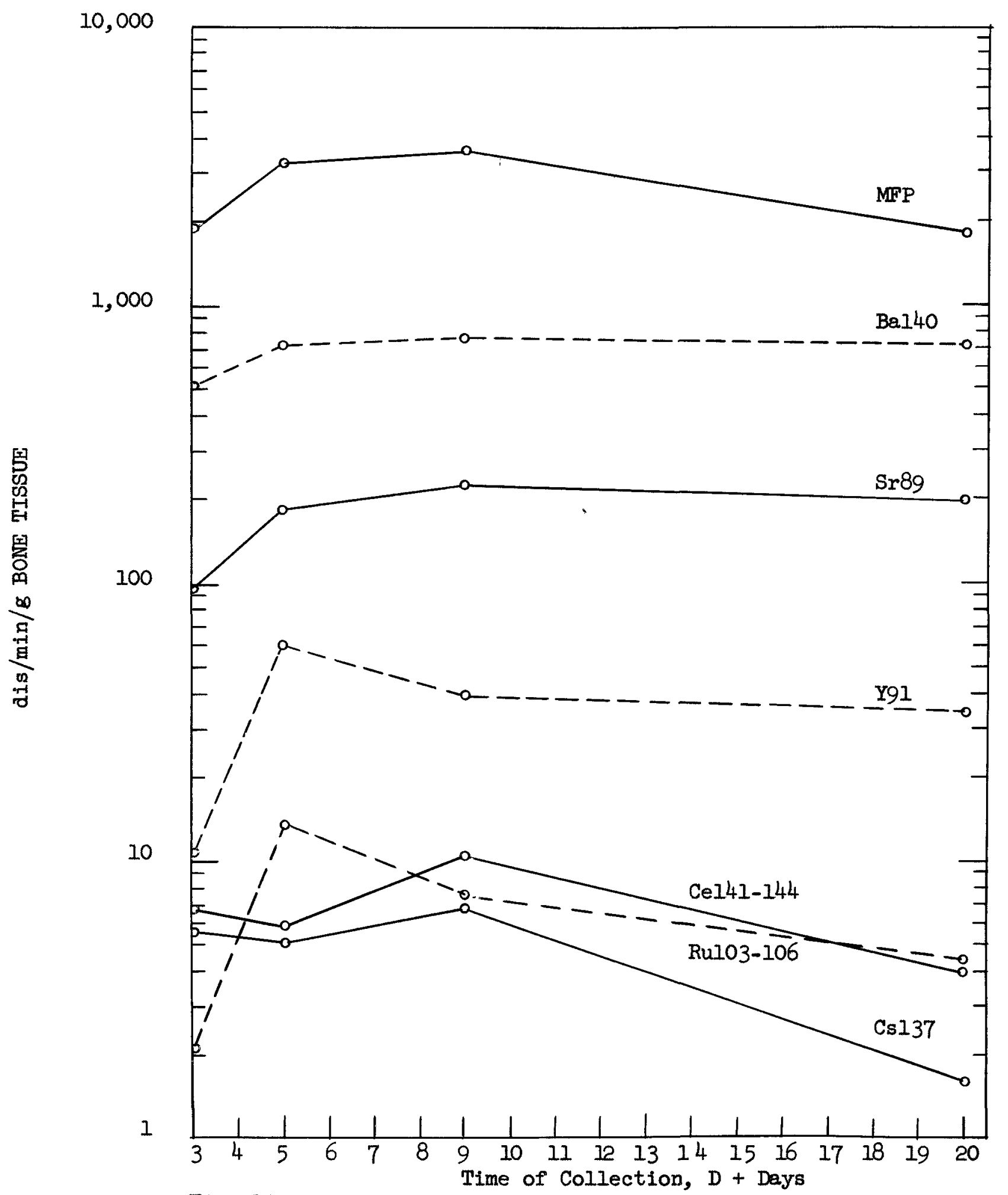

Fig. 12

Radioelement and mixed fission product activities of jack rabbit bone tissue as a function of time of collection at Smoky Station VII 
Effects of chronic exposure of native animals in fallout contaminated areas upon the radiostrontium content in bone tissue have been investigated. Twelve months after the Upshot-Knothole Series (11), and six months after the Teapot Series (5), the accumulated radiostrontium was found to be a function of distance from the point of detonation. The maximum radiostrontium concentrations in rabbit bones occurred at 130 miles from Ground Zero in previously delineated fallout patterns.

Strontium 90 bone concentrations in rabbits collected along Plumbbob fallout patterns approximately twelve months post-series correlated poorly with soil Sr90 levels (9). In areas where surface soil Sr90 levels ranged from 13.8 to $142 \mathrm{mc} \mathrm{Sr90/sq.} \mathrm{mi.} \mathrm{and} \mathrm{from} 2.5$ to $406 \mathrm{Sr} 90 / \mathrm{g} \mathrm{Ca}$, bone contents ranged from 10 to $22 \mu \mu \mathrm{c} \mathrm{Sr} 90 / \mathrm{g}$ Ca with some of the lowest bone contents coinciding with high levels of soll contamination.

The Sr90 level in the bones of male Big Horn sheep from the Desert Game Range, Clark County, Nevada, collected during the 1956 and 1957 hunting seasons, or pre- and post-Plumbbob Operation, was determined (12). Approximately 20 specimens were analyzed from each season. The mean Sr90 content for 1956 was $2.8 \mu \mu \mathrm{c}$ Sr90/B Ca. The corresponding value for 1957 was 6.6 $\mu \mu \mathrm{C}$ Sr90/8 Ca, or slightly more than double the 1956 level.

A survey of deer bones collected primarily in the NE quadrant of Nevada gave similar results; some levels as high as $25 \mu \mu \mathrm{c}$ Sr90/g Ca were observed. Where samples were obtained during 1956 and 1957 from the same locality, an increase in the Sr90 level during 1957 was quite apparent.

5. Strontium90 Contamination in Milk Produced in Hevada and Utah:

Milk samples collected before, during and immediately after the Plumbbob Test Series from Nevada (Table 7) and Utah (Table 8) farms generally reflected an increase in Strontium Unit ( $\mu$ c $\mathrm{Sr} 90 / \mathrm{g} \mathrm{Ca}$ ) following farm contamination by Plumbbob detonations and a reduction in Strontium Unit with increased time after contamination (1). Data suggest that increases in Sr90 levels of milk produced on farms contaminated by Nevada Test Site fallout could be minimized by immediate reduction of pasture grass consumption following contamination. The substitution of protected or imported feeds for a period of several months will conceivably reduce milk Strontium Unit values to as little as one-third the levels othernise present. 


\section{TABLE 7}

Strontium90 Content of Milk Serially-Sampled at Specific Farms in Nevada

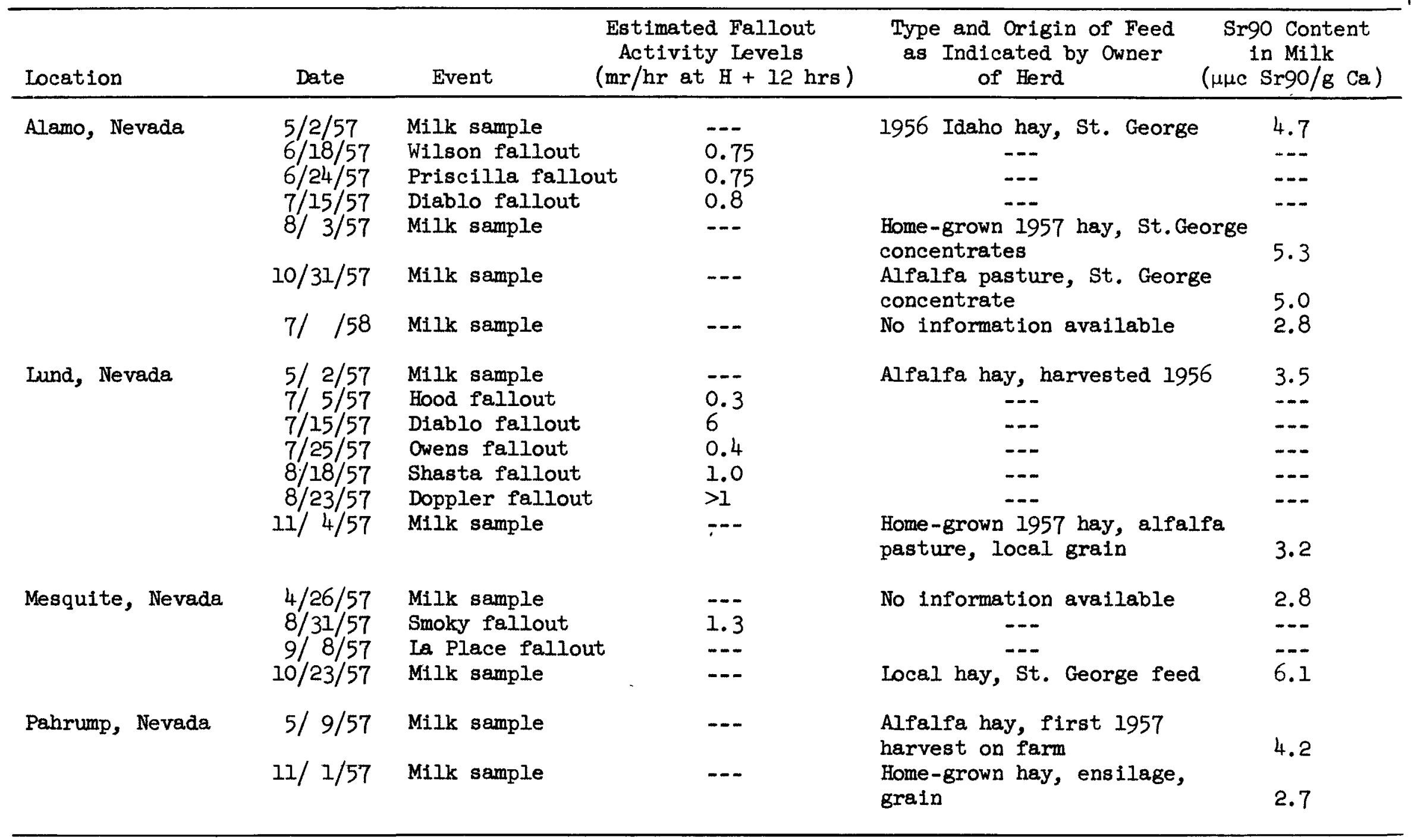


TABLE 8

Strontium 90 Content of Milk Serially-Sampled at Specific Farms in Utah

\begin{tabular}{|c|c|c|c|c|c|c|}
\hline Iocation & Date & $\begin{array}{r}\text { Esti } \\
\text { Act } \\
(\mathrm{mr} / \mathrm{h}\end{array}$ & $\begin{array}{l}\text { ated Fallout } \\
\text { lvity Levels } \\
\text { at } \mathrm{H}+12 \mathrm{hrs} \text { ) }\end{array}$ & $\begin{array}{l}\text { Type and Origin of Feed } \\
\text { as Indicated by Owner } \\
\text { of Herd }\end{array}$ & $\begin{array}{l}\text { r90 Cont } \\
\text { in Mill } \\
\text { Sr } 90 / 8\end{array}$ & $\begin{array}{l}\text { ent } \\
\mathrm{k} \\
\mathrm{Ca})\end{array}$ \\
\hline Antimony, Utah & $\begin{array}{l}8 / 31 / 57 \\
9 / 20 / 57 \\
10 / 21 / 57 \\
7 / / 58\end{array}$ & $\begin{array}{l}\text { Smoky fallout } \\
\text { Milk sample } \\
\text { Milk sample } \\
\text { Milk sample }\end{array}$ & $\begin{array}{c}7 \\
\cdots- \\
---\end{array}$ & $\begin{array}{l}\text { Home-grown hay harvested after } \\
\text { Smoky Shot } \\
50 \% \text { of hay in Smoky fallout } \\
\text { No information available }\end{array}$ & $\begin{array}{r}13.6 \\
10.0 \\
3.5\end{array}$ & \\
\hline Fremont, Utah & $\begin{array}{r}8 / 31 / 57 \\
9 / 9 / 57 \\
9 / 21 / 57 \\
10 / 19 / 57 \\
7 / / 58\end{array}$ & $\begin{array}{l}\text { Smoky fallout } \\
\text { Milk sample } \\
\text { Milk sample } \\
\text { Milk sample } \\
\text { Milk sample }\end{array}$ & $\begin{array}{c}4 \\
--- \\
--- \\
--\end{array}$ & $\begin{array}{l}\text { Home-grown } 1956 \text { hay } 5 \% \text {, pasture } \\
80 \% \text {, commercial feed } \\
\text { No information available } \\
\text { Alfalfa pasture, commercial feed } \\
\text { No information available }\end{array}$ & $\begin{array}{r}12.1 \\
9.5 \\
4.9 \\
4.4\end{array}$ & \\
\hline Milford, Utah & $\begin{array}{r}4 / 29 / 57 \\
8 / 31 / 57 \\
10 / 26 / 57\end{array}$ & $\begin{array}{l}\text { Milk sample } \\
\text { Smoky fallout } \\
\text { Milk sample }\end{array}$ & $<0.5$ & $\begin{array}{l}\text { Home-grown } 1956 \text { hay, home-grown } \\
\text { grain } \\
50 \% \text { pasture, } 50 \% 1957 \text { hay, grain }\end{array}$ & $\begin{array}{l}3.1 \\
2.7\end{array}$ & \\
\hline Panguitch, Utah & $\begin{array}{r}8 / 31 / 57 \\
9 / 8 / 57 \\
9 / 20 / 57 \\
10 / 21 / 57 \\
7 / / 58\end{array}$ & $\begin{array}{l}\text { Smoky fallout } \\
\text { Milk sample } \\
\text { Milk sample } \\
\text { Milk sample } \\
\text { Milk sample }\end{array}$ & 14 & $\begin{array}{l}\text { Local pasture } \\
\text { Local pasture } \\
\text { "Old" hay } \\
\text { No information available }\end{array}$ & $\begin{array}{r}37.3 \\
17.0 \\
26.2 \\
9.7\end{array}$ & \\
\hline St. George, Utah & $\begin{array}{r}4 / 26 / 57 \\
6 / 24 / 57 \\
8 / 3 / 57 \\
8 / 31 / 57 \\
10 / 28 / 57\end{array}$ & $\begin{array}{l}\text { Milk sample } \\
\text { Priscilla fallout } \\
\text { Milk sample } \\
\text { Smoky fallout } \\
\text { Milk sample }\end{array}$ & $\begin{array}{l}0.5 \\
0 .- \\
10 \\
---\end{array}$ & $\begin{array}{l}\text { Home-grown } 1957 \text { hay, first harvest } \\
-- \\
\text { Hay, harvested } 8 / 1 / 57 \\
-- \\
\text { Home-grown } 1957 \text { hay and ensilage, } \\
\text { grain }\end{array}$ & $\begin{array}{l}2.8 \\
-- \\
2.6 \\
-- \\
4.6\end{array}$ & 0 \\
\hline
\end{tabular}


TABLE 8

Strontium 90 Content of Milk Serially-Sampled at Specific Farms in Utah (Cont'd)

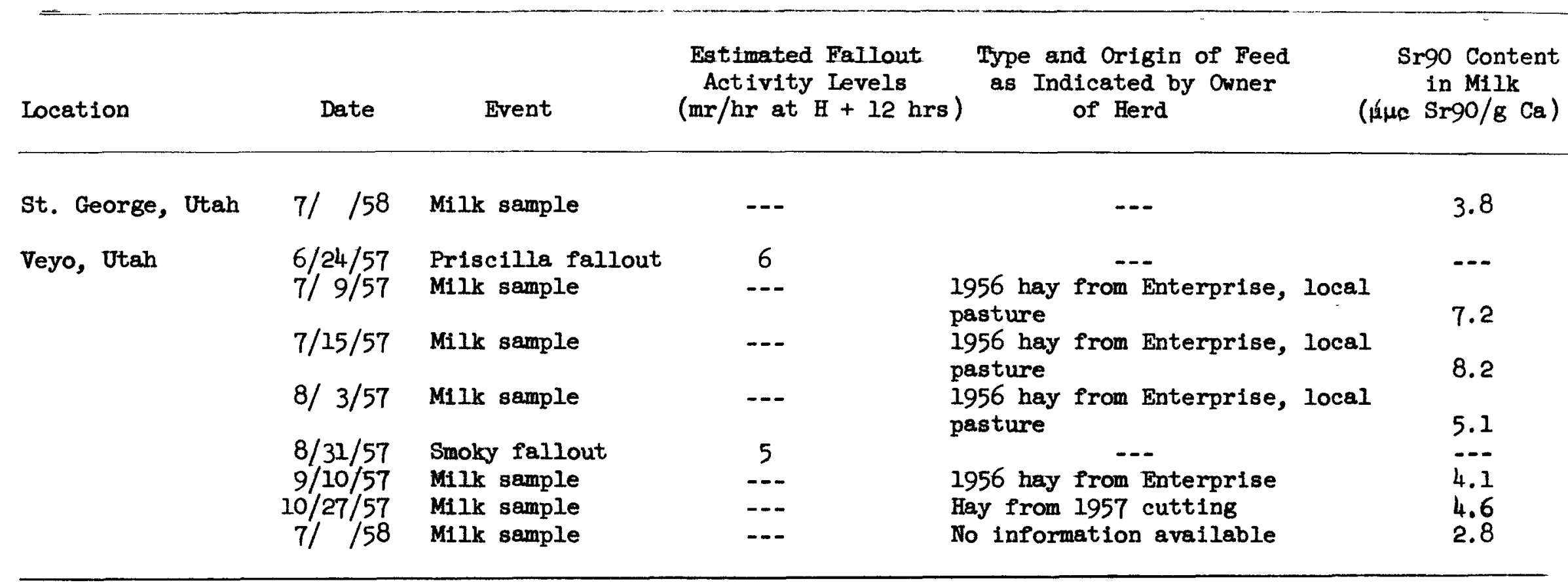


The Strontium Unit values of soll samples collected one year after the Plumbbob series at milk-producing farms were generally 1.5 to 2 times higher than those of corresponding milk samples (9). This lack of correlation may be attributable to a number of factors, among which are: (a) variations in biological avallability of deposited $\operatorname{Sr} 90$; (b) differences in levels of native stable strontium; and (c) variations in the amounts of calcium, stable strontium and Sr9o in the various dairy feeds.

6. Experimentally-Determined Soll-Plant Factors which Affect Sr90 and Cs137 Accumulation in Crops: Several soil and plant factors influence the availability and accumulation of fission products in plants. Radiostrontium was most readily accumulated by crop plants from artificially contaminated soils. Only very small amounts of Y91, Rul06, Cs137, and Ce144 were accumulated $(13,14,15)$.

In a short time experiment ( 21 days), the addition of non-composted organic matter to soils reduced Sr90 uptake by barley seedlings (16, 17$)$. The application of undecomposed organic matter at levels equivalent to $10,20,50$, and 100 tons per acre reduced the uptake of Sr90, 12, 30, 50, and 75 per cent, respectively. The uptake of $\mathrm{Sr} 90$ by tomato plants was also reduced by higher applications of organic matter (17, 19). The influence of the applied organic matter was related to its effect on the soil microbal population and to the change in the chemical composition of the soils as the organic matter decomposed.

The addition of lime $\left(\mathrm{CaCO}_{3}\right)$ and gypsum $\left(\mathrm{CaSO}_{4}\right)$ to acidic soils low in native Ca reduced Sr90 uptake by plants (19, 20). Greatest inhibition occurred at treatment levels equivalent to from 2 to 5 tons per acre. At these levels $\mathrm{CaCO}_{3}$ reduced $\mathrm{Sr} 90$ uptake about 60 per cent; $\mathrm{CaSO}_{4}$ caused an 80 per cent reduction. These Ca amendments had little or no influence on the uptake of Sr90 from neutral and alkaline soils. The uptake of Sr90 was increased by low-level applications of stable $\mathrm{Sr}$ but it was reduced by applications in excess of 5 tons per acre (20, 2l).

The uptake of Csl37 occurring as a contaminant increased as the $K$ concentration in the soil was reduced by prolonged cropping (22, 23). The addition of $\mathrm{K}$ to contaminated soils low in potassium content reduced the uptake of Cs137 by plants. 
Page 36

\section{SUMMARY AND CONCLUSIONS}

The use of aerial surveys has greatly increased the detail and accuracy of fallout pattern delineation. About 25 per cent of the total amount of fission products produced by tower-supported detonations was deposited within distances corresponding to $\mathrm{H}+12 \mathrm{hr}$ fallout time; very much less was deposited by balloon-supported detonations.

Particles less than 44 microns in diameter contained about 30 per cent of the fallout radioactivity from tower-supported detonations as compared to about 70 per cent from balloon-supported detonations within distances corresponding to $\mathrm{H}+12 \mathrm{hr}$ fallout time. Balloon-supported detonations produced fallout debris of higher water and acid solubility than did tower-supported or underground detonations.

The percentage of Sr89, 90 and Rul03, 106 was higher in fallout particles less than 44 microns in diameter than in larger fallout particles. There was a higher percentage of these radioelements in fallout debris from balloon detonations than from tower detonations. The amounts of watersoluble Bal40 and Sr89, 90 deposited locally by a balloon and a towersupported detonation of similar yleld and detonation height were estimated to be similar despite relatively large differences in the total amounts of these radioisotopes deposited. Within distances corresponding to $H+12 \mathrm{hr}$ fallout time, balloon-supported detonations deposited a maximum of 0.13 per cent of the theoretical total Sr89 produced whlle towersupported detonations deposited a maximum of 2 per cent. Tower-supported detonations deposited a maximum of 7.2 per cent of the theoretical total amount of Sr90 produced.

Beta decay curves approximated the $\mathrm{T}^{-1.2}$ decay expression from $\mathrm{H}+12$ to $\mathrm{H}+6000 \mathrm{hrs}$; gamma decay curves deviated to the extent that irradiation doses calculated by the observed decay values were 1.5 to 2 times greater than those calculated by the $\mathrm{T}^{-1.2}$ relationship.

In the environment, fallout radioactivity is apparently confined to the first 2 inches of soil unless the soll was mechanically distributed. The ajority of the fallout debris which was redistributed by various environmental factors on the soll surface after original deposition 
consisted of less than 44 micron diameter particles; this size particle also represented the predominant contamination on forage plants. Strontium 90 surface soll contamination levels in Nevada and Utah in August, 1958, ranged from 31.9 to $142 \mathrm{mc} / \mathrm{sq}$ mile in virgin areas near known fallout pattern midlines and from 7.5 to $22.7 \mathrm{mc} / \mathrm{sq}$ mile in agricultural areas which did not necessarily coincide with fallout pattern midlines.

During the test series operations, the level of uptake of radioiodine by native animals was observed to be a function of distance from Ground Zero. Barium-140, Rul03, 106 and Sr89, 90 were major bone contaminants. Post-series sampling of native animals indicated that the level of uptake of Sr89 was also a function of distance; however, uptake levels of Sr90 correlated poorly with soil contamination or strontium unit levels. Milk samples collected from Nevada and Utah farms before, during and after the Plumbbob Test Series showed that the strontium unit levels increased in milk immediately following contamination of the farm with fallout debris, and then decreased with time.

Radioecological studies clearly indicated that biological effect or hazard cannot be assessed realistically on the basis of measurements of only the gamma radiation field. Fission products from radioactive fallout debris could be assimilated by animals with the maximum degree of accumulation occurring not necessarily near the source of the nuclear detonation. Furthermore, within a distance of 10 to 400 miles from the Nevada Test Site, the plant foliage is a selective collector of small sized fallout particles and is the predominant source of radioactive contaminants to foraging animals. No significant accumulation of radioactive fission products through the root system has been observed in this area during the cropping periods immediately following fallout contamination. Biological avaliability of fallout debris is strongly influenced by the conditions of fallout contamination and by the physical and chemical nature of the contaminating debris and its interaction with climatic, biotic and edaphic factors.

Observations during the past decade indicate that less than 10 per cent of the total theoretical Sr89 and Sr90 produced from all nuclear detonations at Nevada Test Site since the Ranger Series (1951) has been deposited within 200 miles from the point of detonation. 
Page 38

\section{ACKNOWLEDGMENTS}

The authors gratefully extend their thanks to the many personnel, their agencies and laboratories whose individual efforts and contributions made it possible to present this summary report. We are especially indebted to Dr. A. C. Graves, Chairman of the Planning Board, Weapons Test Programs; Dr. C. L. Dunham, Director, Division of Biology and Medicine AEC; Mr. James Reeves, Test Manager, and his staff; and to Mr. R. I. Corsble, Director of the Civil Effects Test Group for their numerous suggestions, encouragement and support in accomplishing the objectives of the various fallout studies during the several Weapons Test Programs.

Also our sincere thanks is extended to the various members of the staff of our Laboratory and the Environmental Radiation Division for their contributions and support in all phases of the various programs. 
Page 39

\section{REFERENCES}

(1) Larson, K. H. et al. Radio-ecological aspects of nuclear fallout. WT-1488 (to be published)

(2) Bellamy, A. W., et al. 1949 The 1948 radiological and biological survey of areas in New Mexico affected by the first atomic bomb detonation. UCLA-32

(3) Rainey, C. T., et al. 1954 Distribution and characteristics of fallout at distances greater than ten miles from Ground Zero, March and April, 1953, (Operation Upshot/Knothole) WT-811

(4) Beurmash, L., et al. 1958 Distribution and characterization of fallout and airborne activity from 10 to 160 miles from Ground Zero, Spring 1955 (Operation Teapot) WT-1178

(5) Lindberg, R. G., et al. 1959 The factors influencing the biological fate and persistence of radioactive fallout (Operation Teapot) WT- 1177

(6) Olafson, J. H. et al. 1953 Preliminary study of off-site airborne radioactive materials, Nevada Proving Grounds. I. Fallout originating from Snapper 6, 7, and 8 at distances 10 to 50 miles from Ground Zero. UCLA-243

(7) Larson, K. H. et al. 1952 Field observations and preliminary field data obtained by the UCLA Survey Group, Operation Jangle, November 1951. UCLA-182

(8) Olafson, J. H., et al. 1957 The distribution of plutonium in the soils of central and northeastern New Mexico as a result of the Atomic Bomb test of July 16, 1945. UCLA-406

(9) Larson, K. H., et al. Strontium9o levels of soil, plants, animals and milk at selected locations in Nevada and Utah: 1958 and 1959. (To be published).

(10) Larson, K. H., et al. 1953 The uptake of radioactive fission products by radishes and Ladino clover from soil contaminated by actual subsurface detonation fallout materials. UCLA-272

(II) Lindberg, R. G., et al. 1954 Environmental and biological fate of fallout from nuclear detonation in areas adjacent to the Nevada Proving Grounds. WT-812

(12) Unpublished data.

(13) Neel, J. W., et al. 1953 Soll-plant interrelationships with respect to the uptake of fission products. I. The uptake of Sr90, Cs137, Rul06, Ce144, and Y91。 UCLA-247 
Page 40

(14) Romney, E. M., et al 1954 Plant uptake of Sr90, Ru106, Cs137 and Cel44 from three different types of solls. UCLA-294

(15) Romney, E. M., et al 1957 Plant uptake of Sr90, Y91, Rul06, Cs137, and Cel44 from solls. Soll Science 83: 369-376.

(16) Nishita, H., et al. 1955 The influence of soll organic matter on the uptake of Sr90 by barley and tomato plants. UCLA-349.

(17) Nishita, H., et al. 1956 Influence of soil organic matter on mineral uptake by barley seedlings. Soll Science 82: 307-318.

(18) Nishita, H., et al. 1956 Influence of soll organic matter on mineral uptake by tomato plants. Soll science 82: 401-407.

(19) Romney, E. M., et al. 1956 Effects of calcium and strontium on plant uptake of Sr90 and stable strontium from nutrient solutions and solls. UCLA- 374 .

(20) Romney, E. M., et al. 1959 Influence of calcium on plant uptake of Sr90 and stable strontium. Sol1 Science 87: 160-165. (March)

(21) Romney, E. M., et al. 1959 Influence of stable Sr on plant uptake of Sr90 from soils. Soil Science 87: 42-45. (January).

(22) Nishita, H., et al. 1956 The release of Sr90 and Csl37 from Vina loam upon prolonged cropping. UCLA 380 .

(23) Nishita, H., et al. 1958 Release of Sr90 and Csl37 from Vina loam upon prolonged cropping. Soil sclence 86: 195-201. (October.) 